Time, History, and Literature 



\section{Time, History, and Literature}

Selected Essays of Erich Auerbach

Edited and with an introduction by James I. Porter

Translated by Jane O. Newman

P R I NCETON U N I ER S T Y PRES S

Princeton \& Oxford 
Copyright $\odot 2014$ by Princeton University Press

Published by Princeton University Press, 41 William Street, Princeton, New Jersey 08540 In the United Kingdom: Princeton University Press, 6 Oxford Street,

Woodstock, Oxfordshire OX20 1TR

$$
\text { press.princeton.edu }
$$

Cover Art: Paolo Uccello (1397-1475), The Great Flood, S. Maria Novella, Florence, Italy. Photo: George Tatge for Alinari, 1998. Courtesy of Alinari / Art Resource, NY

$$
\text { All Rights Reserved }
$$

Second printing, and first paperback printing, 2016

Paperback ISBN: 978-0-691-16907-1

The Library of Congress has cataloged the cloth edition as follows Auerbach, Erich, 1892-1957.

Time, history, and literature : selected essays of Erich Auerbach / edited and with an introduction by James I. Porter ; translated by Jane O. Newman.

$$
\text { pages } \mathrm{cm}
$$

Includes bibliographical references and index.

ISBN 978-0-691-13711-7 (acid-free paper) 1. Literature-History and criticism-Theory, etc. 2. Critics-Germany. 3. Criticism-Germany. 4. Literary historians-Germany. I. Porter, James I., 1954- editor of compilation. II. Newman, Jane O., translator. III. Title.

$$
\text { PN504.A94 } 2014
$$

$$
809-\mathrm{dc} 23 \quad 2013013528
$$

British Library Cataloging-in-Publication Data is available

The translation of this work was supported by a grant from the Goethe-Institut, which is funded by the German Ministry of Foreign Affairs.

This book has been composed in Minion and Ideal Sans

Printed on acid-free paper $\infty$

Printed in the United States of America

$\begin{array}{lllllllll}3 & 5 & 7 & 9 & 10 & 8 & 6 & 4 & 2\end{array}$ 